\title{
Hubungan Kemandirian Belajar dengan Pemahaman Konsep IPA Siswa Kelas IV SDN Gugus III Gunungsari
}

\author{
Dian Nurhayati ${ }^{1 *}$, Lalu Hamdian Affandi', Baiq Niswatul Khair ${ }^{1}$ \\ 'Program Studi Pendidikan Guru Sekolah Dasar, Universitas Mataram, Mataram, Indonesia \\ "Corresponding author: 15diannur9819@gmail.com
}

\begin{abstract}
Abstrak: Penelitian ini bertujuan untuk mengetahui hubungan kemandirian belajar dengan pemahaman konsep IPA siswa kelas IV SDN Gugus III Gunungsari tahun 2020/2021. Populasi dalam penelitian ini yaitu seluruh siswa kelas IV SDN Gugus III Gunungsari yang berjumlah 197. Jenis penelitian yang digunakan dalam penelitian ini adalah penelitian kuantitatif dengan metode korelasi. Sampel penelitian ini berjumlah 30 siswa yang diambil dengan menggunakan tehnik judgement (pertimbangan) metode yang digunakan untuk pengambilan data yaitu angket dan tes. Data diperoleh, diolah dengan teknik analisis korelasi. Hasil penelitian menunjukkan bahwa terdapat hubungan positif antara kemandirian belajar dengan pemahaman konsep IPA siswa kelas IV SDN Gugus III Gunungsari yang ditunjukkan oleh hasil korelasi product moment dimana $r_{\text {hitung }}>r_{\text {tabel }}$ pada taraf signifikansi $5 \%$ yakni 0,503 >0,361, sehingga Ha diterima. ini berarti terdapat hubungan yang signifikan antara kemandirian belajar dengan pemahaman konsep IPA dengan taraf signifikansi 5\% sebesar 0,503. Jika kemandirian belajar siswa tinggi, maka pemahaman konsep IPA siswa juga tinggi.
\end{abstract}

Kata Kunci: kemandirian belajar, pemahaman konsep, IPA, Sekolah Dasar

\begin{abstract}
The purpose of this research aims to know the relationship of learning independence with the understanding of the concept of science students of grade IV SDN Cluster III Gunungsari in 2020/2021. The population in this study was all grade IV students of SDN Cluster III Gunungsari which amounted to 197. The type of research used in this study is quantitative research with correlation method. The sample of this study amounted to 30 students who were taken using the technique judgement (consideration) method used for data retrieval, namely questionnaires and tests. The data is obtained, processed by correlation analysis techniques. The results showed that there is a positive relationship between the independence of learning and the understanding of the concept of science students grade IV SDN Cluster III Gunungsari shown by the results of product moment correlation where $r$-value $>r$-table at the level of significance $5 \%$ namely $0.503>0.361$, so that Ha is accepted. this means there is a significant relationship between the independence of learning and the understanding of the concept of science with a 5\% significance level of 0.503. If the independence of students' learning is high, then the understanding of the concept of student science is also high.
\end{abstract}

Keywords: independent learning, concept understanding, science, elementary school

\section{PENDAHULUAN}

Pembelajaran adalah suatu proses interaksi antar siswa dengan lingkungannya baik antar siswa dengan siswa, siswa dengan pendidik maupun siswa dengan sumber belajar (Undangundang No. 20 Tahun 2003 tentang Sistem Pendidikan Nasional). Pembelajaran pada dasarnya merupakan upaya pendidik untuk membantu siswa dalam melaksanakan kegiatan belajar untuk mencapai hasil belajar. Hasil belajar ditandai dengan salah satu ciri yaitu siswa mampu menghubungkan pengetahuan baru dengan pengetahuan lama. Kemampuan menghubungkan 
pengetahuan baru dengan pengetahuan lama disebut pemahaman (Anderson \& Krathwohl, 2017:106).

Parker (2006) menjelaskan bahwa pemahaman konsep menjadi dasar pengembangan pengetahuan siswa dan merupakan kunci keberhasilan suatu pembelajaran, karena pemahaman menunjuk pada penjelasan terhadap suatu konsep yang lebih bermakna (dalam Purwati dkk, 2016:479). Dalam hal itu siswa bukan hanya mengetahui pengetahuan yang relevan, tetapi juga dapat memahami konsep-konsep baru serta dapat menggunakannya untuk menyelesaikan masalah dalam kehidupan sehari-hari (Anderson \& Krathwohl, 2017:97). Pemahaman Konsep adalah kemampuan siswa untuk memahami konsep-konsep yang meliputi kemampuan menafsirkan, memberikan contoh, mengklasifikasi, meringkas, menduga, membandingkan dan menjelaskan mengenai suatu fenomena-fenomena yang ditemui dalam kehidupan sehari-hari. Oleh sebab itu, siswa diharapkan dapat mengembangkan pengetahuan dan pemahamannya yang akan bermanfaat dikemudian hari melalui belajar mandiri. Jadi pemahaman konsep dapat diartikan sebagai kemampuan menangkap makna suatu konsep dengan kata-kata sendiri yang dinyatakan dalam definisi sehingga melahirkan suatu produk pengetahuan.

Berdasarkan hasil observasi yang telah dilakukan pada kelas IV gugus III Gunungsari, terdapat 5 sekolah dasar yakni SDN 1 Midang, SDN 2 Midang, SDN 3 Midang, SDN 1 Kekeri dan SDN 2 Kekeri. Di mana fakta yang sering terjadi di lapangan menunjukkan bahwa siswa kurang fokus ketika belajar, ada yang enggan, malu, bahkan takut untuk mengemukakan pendapatnya. Terdapat siswa yang terlambat dan lamban dalam menangkap pelajaran. Selain itu siswa belajar ketika mendekati ujian, tidak betah belajar lamban, siswa belajar hanya pada saat diperintah belajar, dan ketika diperintah mengerjakan soal siswa menyontek/menunggu jawaban dari temannya. Masalah-masalah tersebut sudah menjadi kebiasaan siswa pada saat proses pembelajaran. Oleh sebab itu kemandirian belajar sangat mempengaruhi kehidupan siswa.

Siswa yang memiliki kemandirian belajar tinggi cenderung mempunyai pemahaman konsep yang baik. Hal tersebut senada dengan penelitian yang dilakukan oleh (Egok, 2016: Rahmawati, 2016). Adapun hasil penelitian yang dilakukan oleh Egok \& Rahmawati menunjukkan adanya hubungan positif yang signifikan antara kemandirian belajar dengan hasil belajar siswa. Dimana siswa yang memiliki kemandirian belajar yang positif akan membuat siswa proaktif dan memiliki tanggung jawab terhadap proses belajar yang dilakukannya serta berupaya sebaik mungkin untuk berhasil dalam belajar agar memperoleh hasil belajar yang memuaskan.

Kemandirian belajar merupakan kemampuan siswa dalam belajar tanpa bantuan dari pihak luar atau sering disebut belajar atas dasar kemauannya sendiri tanpa adanya paksaan dari orang lain. Listyani (2008) kemandirian belajar adalah kemampuan untuk tidak tergantung pada orang lain, memiliki kepercayaan diri, berperilaku disiplin, memiliki rasa tanggung jawab, berperilaku berdasarkan inisiatif sendiri dan melakukan kontrol diri (dalam Saefullah dkk, 2013:27). Kemandirian belajar diawali dengan suatu kesadaran adanya masalah, sehingga menimbulkan niat melakukan kegiatan belajar secara sengaja untuk menguasai suatu kompetensi yang diperlukan guna mengatasi masalah.

Kemandirian belajar sangat penting, karena siswa yang memiliki kemandirian belajar yang tinggi akan berusaha menyelesaikan segala latihan atau tugas yang diberikan oleh guru dengan kemampuan yang dimilikinya secara optimal dan tidak menggantungkan diri kepada orang lain (Al Fatihah, 2016:201). Kemandirian belajar adalah suatu proses belajar dimana setiap individu dapat mengambil inisiatif, dengan atau tanpa bantuan orang lain dalam hal menentukan kegiatan belajarnya seperti merumuskan tujuan belajar, sumber belajar (baik merupakan orang atau bahan), mendiagnosis kebutuhan belajar dan mengontrol sendiri proses belajarnya (Sundayana, 2016:78).

Oleh karena itu, berdasarkan uraian mengenai kemandirian belajar dan hubungannya dengan pemahaman konsep, maka peneliti tertarik untuk menyelidiki hubungan kemandirian belajar dengan pemahaman konsep IPA siswa khususnya siswa kelas IV SDN Gugus III Gunungsari tahun $2020 / 2021$. 


\section{METODE PENELITIAN}

Jenis penelitian yang digunakan adalah penelitian kuantitatif. Metode yang digunakan adalah korelasi dengan bentuk hubungan kasual (sebab-akibat). Hubungan antara satu variabel satu dengan beberapa variabel dinyatakan dengan besarnya koefisien korelasi dan keberartian (signifikansi) secara statistik (Sukmadinata, 2011:56). Metode pengumpulan data yang digunakan dalam penelitian ini, yakni dengan menggunakan angket, angket yang digunakan pada penelitian ini berupa angket tertutup. Angket ini berupa checklist, disususn dengan menggunakan skala likert yang berisi pernyataan mengacu pada indikator penelitian. Untuk memperoleh gambaran hasil kemandirian belajar siswa. Sedangkan tes digunakan untuk memperoleh data tentang kemampuan pemahaman konsep IPA siswa. Tes yang digunakan yaitu tes objektif berbentuk soal pilihan ganda. Sampel dari penelitian ini berjumlah 30 sampel yang ditentukan dengan teknik judgement (pertimbangan) yang dibagi dalam 3 lokasi, yaitu 10 sampel di SD Negeri 3 Midang, 10 sampel di SD Negeri 2 Kekeri dan 10 sampel di SD Negeri 1 Kekeri. Untuk menguji dan mencari hubungan kemandirian belajar dengan pemahaman konsep IPA siswa digunakan uji korelasi pearson ( $r$ ) dan uji regresi. Analisis dilakukan menggunakan bantuan SPSS 25 pada taraf $5 \%$. Tetapi sebelum dilakukan uji korelasi dan uji regresi terlebih dahulu dilakukan uji prasyarat, yaitu uji normalitas dan uji linearitas. Pengujian hipotesis dalam penelitian ini menggunakan analisis korelasi product moment.

\section{HASIL DAN PEMBAHASAN}

Hasil penelitian mengenai kemandirian belajar siswa dan data mengenai pemahaman konsep IPA Siswa Sekolah dasar disajikan pada Tabel 1 dan Tabel 2.

Tabel 1. Distribusi Frekuensi Kemandirian Belajar Siswa

\begin{tabular}{cccc}
\hline Interval & Kategori & Frekuensi & Persentase \\
\hline $65 \leq X \leq 80$ & Sangat Baik & - & - \\
$55 \leq X<65$ & Baik & 5 & $17 \%$ \\
$45 \leq X<55$ & Sedang & 20 & $66 \%$ \\
$35 \leq X<45$ & Kurang Baik & 5 & $17 \%$ \\
$20 \leq X<35$ & Tidak Baik & - & - \\
\hline
\end{tabular}

Tabel 2. Distribusi Frekuensi Kemandirian Belajar Siswa

\begin{tabular}{cccc}
\hline Interval & Kategori & Frekuensi & Persentase \\
\hline$X<2$ & Tidak baik & - & - \\
$2 \leq X<6$ & Kurang baik & 3 & $10 \%$ \\
$6<X \leq 10$ & Sedang & 25 & $83 \%$ \\
$10<X \leq 14$ & Baik & 2 & $7 \%$ \\
$14<X$ & Sangat baik & - & - \\
\hline
\end{tabular}

Berdasarkan Tabel 1 dapat diketahui bahwa dari data kemandirian belajar siswa diperoleh kategori kurang baik terdapat 5 siswa dengan persentase sebesar $17 \%$, kategori sedang terdapat 20 siswa dengan persentase $66 \%$ dan pada kategori baik terdapat 5 siswa dengan persentase sebesar $17 \%$. Berdasarkan data ini dapat diketahui bahwa kemandirian belajar siswa di Sekolah dasar di Gunungsari pada tahun pelajaran 2020/2021 masih dalam kategori sedang.

Data mengenai pemahaman konsep IPA siswa sekolah dasar di Gunungsari pada tahun pelajaran 2020/2021 yang dapat dilihat pada Tabel 2 diperoleh bahwa terdapat kategori kurang baik terdapat 3 siswa dengan persentase sebesar 10\%, kategori sedang terdapat 25 siswa dengan persentase $83 \%$ dan pada kategori baik terdapat 2 siswa dengan persentase sebesar 7\%. Dari uraian data ini diperoleh hasil bahwa tingkat pemahaman konsep IPA siswa sekolah dasar di Gunungsari masih dalam kategori sedang.

Uji normalitas dilakukan pada data kemandirian belajar dan pemahaman konsep IPA menggunakan bantuan SPSS 25 dengan uji Kolmogorov. Hasil tersebut menunjukkan data 
kemandirian belajar dan pemahaman konsep IPA berdistribusi normal pada taraf signifikan 5\%. Untuk mengetahui adanya korelasi dilakukan uji linearitas. Dalam penelitian ini, pengujian linearitas dilakukan dengan bantuan SPSS 25. Jika kedua data tersebut sudah linear maka uji hipotesis dapat dilakukan. Karena uji linearitas ini merupakan salah satu syarat untuk melanjutkan pengujian hipotesis. Hasil test of linearity didapatkan nilai sig. 0,145 sehingga data tersebut linera karena merujuk pada kaidah pengambilan keputusan bahwa Jika nilai Sig. $\geq 0,05$, artinya data linear.

Pengujian hipotesis menggunakan analisis korelasi product moment dengan bantuan SPSS 25. Untuk penentuan uji hipotesis dapat dilakukan dengan membandingkan nilai $r_{\text {hitung }} 0,503$ dengan nilai $r_{\text {tabel }} 0,361$ dimana nilai $r_{\text {hitung }}>r_{\text {tabel }}$ pada taraf signifikansi $5 \%$ dengan $N=30$. Kesimpulannya adalah ada hubungan yang signifikan antara kemandirian belajar dengan pemahaman konsep IPA siswa kelas IV SDN Gugus III Gunungsari. Uji regresi bertujuan mengetahui arah hubungan dan memprediksi nilai dari variabel dependen apabila nilai variabel independen mengalami kenaikan atau penurunan. Hasil perhitungan regresi memperoleh nilai koefisien konstanta sebesar 1.974 koefisien variabel bebas $(X)$ adalah sebesar 0,125 . sehingga persamaan regresi $Y=1.974+0,125 X$. Secara matematis, nilai konstanta ini menyatakan bahwa pada saat kemandirian belajar 0, maka pemahaman konsep IPA memiliki nilai 1.974. Selanjutnya nilai positif $(0,125)$ yang terdapat pada koefisien regresi variabel bebas (kemandirian belajar) menggambarkan bahwa arah hubungan antara variabel bebas (kemandirian belajar) dengan variabel terikat (pemahaman konsep IPA) adalah searah, dimana setiap kenaikan satu variabel kemandirian belajar akan menyebabkan kenaikan pemahaman konsep IPA sebesar 0,125.

Peneliti telah melakukan perhitungan Berdasarkan hasil analisis data menggunakan Product Moment dengan $\mathrm{N}=30$ pada taraf signifikan $5 \%$, menunjukkan hasil bahwa $r_{\text {hitung }}$ $0,503>r_{\text {tabel }}$ 0,361, maka $\mathrm{H}_{\mathrm{a}}$ (hipotesis alternatif) diterima dan (hipotesis nol) ditolak. Sehingga dapat disimpulkan bahwa terdapat hubungan antara kemandirian belajar dengan pemahaman konsep IPA siswa kelas IV SDN Gugus III Gunungsari Tahun 2020/2021 dan besar korelasi kemandirian belajar dengan pemahaman konsep IPA siswa sebesar 0,503 termasuk dalam kriteria sedang.

\section{KESIMPULAN}

Berdasarkan data yang diperoleh dari hail analisis yang dilakukan maka kesimpulan yang dikemukakan dalam penelitian ini adalah sebagai berikut: Ada Hubungan yang signifikan antara Kemandirian Belajar dengan Pemahaman Konsep IPA siswa SDN Gugus III Gunungsari. Hal tersebut ditunjukkan dengan koefisien korelasi $r_{\text {hitung }}$ sebesar 0,503. Lebih besar dari pada harga $r_{\text {tabel }}$ dengan taraf signifikan $5 \%$ dengan $\mathrm{N}=30$ yaitu sebesar 0,361 . Artinya, semakin tinggi kemandirian belajar siswa maka semakin tinggi pula tingkat pemahaman konsep IPA yang dimiliki siswa. Sebaliknya, semakin rendah kemandirian belajar siswa maka semakin rendah pula pemahaman konsep IPA yang dimiliki siswa. Hasil penelitian ini dapat dijadikan sebagai referensi untuk peneliti lain yang akan melakukan penelitian terkait kemandirian belajar, karena hasil hasil dari peneliti ini kurang dari sempurna, dianjurkan bagi peneliti untuk lebih baik dalam melakukan penelitian dan hendaknya mengadakan penelitian yang lebih luas berkaitan dengan kemandirian belajar.

\section{UCAPAN TERIMA KASIH}

Peneliti mengucapkan terimakasih kepada dosen pembimbing yang telah meluangkan waktu untuk membimbing peneliti hingga terselesaikannya artikel ini. Ucapan terimakasih juga disampaikan kepada kepala sekolah serta guru-guru di SDN Gugus III Gunungsari yang telah terlibat aktif selama kegiatan penelitian.

\section{DAFTAR PUSTAKA}

Al Fatihah, M. 2016. Hubungan Antara Kemandirian Belajar dengan Prestasi Belajar PAI Siswa Kelas III SDN Panularan Surakarta. At-Tarbawi. 197-208. 
Anderson, L. W., \& Krathwohl, D. R. 2017. Kerangka Landasan Utama Pembelajaran, Pengajaran dan Asesmen. Yogyakarta: Pustaka Belajar.

Egok, Asep Sukenda. 2016. Kemampuan Berpikir Kritis dan Kemandirian Belajar dengan Hasil Belajar Matematika. Jurnal Pendidikan Dasar. 186-199.

Purwati, Siwi., Supriyono Koes Handayanto dan Siti Zulaika. 2016. Korelasi Antara Penalaran Ilmiah dan Pemahaman Konsep Siswa pada Materi Usaha dan Energi. Pros. Semnas. Pend. IPA Pascasarjana UM: 479-483.

Rahmawati, Desi. 2016. Hubungan Antara Kemandirian Belajar dengan Hasil Belajar Siswa SD Negeri Purwoyoso 06 Semarang. Skripsi.

Saefullah A, Siahaan P, Dan Sari I M. 2013. Hubungan Antara Sikap Kemandirian Belajar dan Prestasi Belajar Siswa Kelas X Pada Pembelajaran Fisika Berbasis Portofolio. Jurnal Wahana Pendidikan Fisika. 26-36.

Sukmadinata, Nana Syaodih. 2011. Metode Penelitian Pendidikan. Bandung: PT Remaja Rosdakarya.

Sundayana, Rostina. 2016. Kaitan Antara Gaya Belajar, Kemandirian Belajar, Kemampuan Pemecahan Masalah Siswa SMP dalam Pelajaran Matematika. Jurnal Pendidikan Matematika STKIP Garut. 75-84. 